\title{
ANALISA DAN PERANCANGAN MODEL KEPUTUSAN BAKAT DAN MINAT ANAK
}

\author{
Anastasya Latubessy \\ Fakultas Teknik, Program Studi Teknik Informatika \\ Universitas Muria Kudus \\ Email: anastasyalatubessy@gmail.com \\ Rina Fiati \\ Fakultas Teknik, Program Studi Teknik Informatika \\ Universitas Muria Kudus \\ Email:rfiati003@yahoo.com
}

\begin{abstract}
ABSTRAK
Analisa dan Perancangan yang baik diperlukan untuk menghasilkan sebuah sistem yang handal. Kebanyakan pengembang program mengabaikan langkah ini, dengan langsung mengerjakan tahap implementasi sistem. Padahal disisi lain, dokumentasi sistem sangat diperlukan untuk pengembangan sistem nantinya. Berdasarkan hal tersebut, penulis melakukan analisa dan perancangan untuk membangun sebuah model keputusan bakat dan minat pada anak SD Kelas 3, 4 dan 5. Model Bayesian digunakan sebagai analisa model keputusan. Sementara Diagramdiagram UML digunakan dalam perancangan sistem. Diagram yang digunakan meliputi use case diagram, activity diagram, sequance diagram dan class diagram. Dengan adanya analisa dan perancangan ini, dapat digunakan sebagai dasar implementasi sistem ke depan. Menghasilkan model keputusan dengan Bayesian yang dapat digunakan untuk penentuan bakat dan minat anak, dengan lima alternatif kemampuan anak.
\end{abstract}

Kata kunci: analisa, perancangan, model, keputusan, bakat, minat.

\section{ABSTRACT}

Analysis and design are both needed to produce a reliable system. Most developers program skip this step, by directly working on the implementation phase. Yet on the other hand, the documentation system is needed for the development of future systems. Based on this, the authors analyze and design to build a model of decision talent and interest in elementary school children grades 3, 4 and 5. The model is used as an analytical Bayesian decision model. While UML diagrams used in the system design. Diagrams are used include the use case diagram, activity diagram, sequance diagram and class diagram. With the analysis and design, can be used as a basis for the future implementation of the system. Produce models with Bayesian decision that can be used to determined talents and interests of children, using five alternative child's ability.

Keywords: analysis, design, model, decision, talent, interest.

\section{PENDAHULUAN}

Bakat (aptitude) adalah kemampuan bawaan yang merupakan potensi yang masih perlu dikembangkan atau dilatih untuk mencapai suatu kecakapan, pengetahuan dan keterampilan khusus, misalnya kemampuan berbahasa, bermain musik, melukis, dan lain-lain. Untuk bisa terealisasi bakat harus ditunjang dengan minat, latihan, pengetahuan, pengalaman agar bakat tersebut dapat teraktualisasi dengan baik [1].

Berdasarkan hal tersebut, dirasa penting dilakukan penentuan bakat dan minat anak sejak dini. Dalam menentukan bakat dan minat diperlukan pemodelan yang tepat untuk mencapai hasil yang maksimal. Oleh sebab itu, dilakukan suatu pemodelan terhadap penentuan keputusan berdasarkan kriteriakriteria bakat dan minat anak menggunakan pemodelan Bayesian. Pemodelan bayesian digunakan untuk mencari bobot setiap alternatif yang digunakan sebagai model keputusan. Bobot tersebut dijadikan standart dalam penentuan bakat dan minat anak. Data anak yang diambil adalah anak sekolah dasar kelas tiga, empat dan lima. Minat dan bakat yang dihasilkan meliputi pada bidang verbal, numerik, spasial, reasoning, dan kemampuan memori serta kreativitas berfikir.

Penerapan metode-metode dalam sistem pendukung keputusan juga dapat digunakan dalam proses identifikasi kelayakan. Penggunaan metode AHP (Analitycal Hierarchy Process) untuk menentukan jurusan dan fakultas berdasarkan minat dan bakat siswa yang hendak masuk perguruan tinggi. Penelitian 
ini membahas tentang sistem yang bisa membantu para siswa untuk menentukan fakultas, dan jurusan sesuai dengan kemampuan, minat, dan bakat mereka. Cara mengetahui kemampuan, minat, dan bakat mereka dengan melakukan tes psikologis(psikotes) yang dimasukkan ke dalam metode AHP dan diterapkan ke dalam mobile web [2].

Penggunaan dasar psikotes juga dilakukan oleh [3] untuk membuat situs web psikotes yang bisa digunakan sebagai media latihan bagi para calon pegawai negeri sipil. Penelitian ini membahas tentang situs web yang berisi soal-soal psikotes yang dapat digunakan sebagai media latihan bagi para calon pegawai negeri sipil. Aspek-aspek psikologis yang diujikan pada penelitian ini yaitu tentang motivasi berprestasi, stabilisasi emosi, hubungan sosial, penyesuaian diri, kemandirian, komunikasi, kerja sama dan kepemimpinan.

Konsep pengambilan keputusan pertama kali diungkapkan pada awal tahun 1970-an oleh Michael S.Scott Morton dengan istilah Manajemen Decission Systems. Menurut Raymond McLeod, Jr, Sistem Pendukung Keputusan adalah sistem penghasil informasi spesifik yang ditujukan untuk memecahkan masalah terterntu yang harus dipecahkan oleh manajer pada berbagai tingkatan. Man dan Watson mendefenisikan SPK sebagai suatu sistem interaktif, yang membantu pengambil keputusan melalui penggunaan data dan model-model keputusan untuk memecahkan masalah-masalah yang sifatnya semi terstruktur dan tidak terstruktur[4].

Penerapan Bayes dalam kasus yang berbeda telah dilakukan oleh Latubessy, A dan Anggraini, L pada jurnal di tahun 2013, menggunakan model bayes sebagai model untuk memilih SIM Card yang sesuai dengan kebutuhan pengguna serta membandingkan perhitungan yang sama dengan menggunakan metode GAP. Pemakaian Bayes pada_pemodelan dan implementasi mampu memberikan perbedaan pada nilai akhir dari perhitungan dengan menghilangkan kemungkinan dua laternatif yang memiliki nilai akhir yang sama. Hal yang sama tidak dapat dilakukan dengan metode GAP[5].

\section{METODOLOGI PENELITIAN}

\subsection{Analisa Kebutuhan}

Dalam membuat pemodelan sistem dibutuhkan data, diantaranya Data Siswa SD kelas 3, 4 dan 5, Data Subtes, Data Doal, Data Bobot, Data Alternatif, Data Hasil. Berdasarkan data-data tersebut, diharapkan dapat menghasilkan sebuah pemodelan keputusan yang dapat digunakan untuk Menjawab Soal, Input data diri, Melihat hasil alternatif, Latihan soal dan Melihat score.

\subsection{Perancangan Diagram Arsitektur SPK}

Pada rancangan arsitektur SPK bakat minat yang dibangun terdapat data internal, dan data ekternal yang diekstrasi ke dalam database dan model base seperti yang ditunjukan pada Gambar1. Data Internal meliputi data siswa, data subtes, data soal, data bobot, data hasil dan data alternatif. Sementara eksternal meliputi UU yang terkait, silabus SD kelas 3,4,5, serta kode etik psikologi.

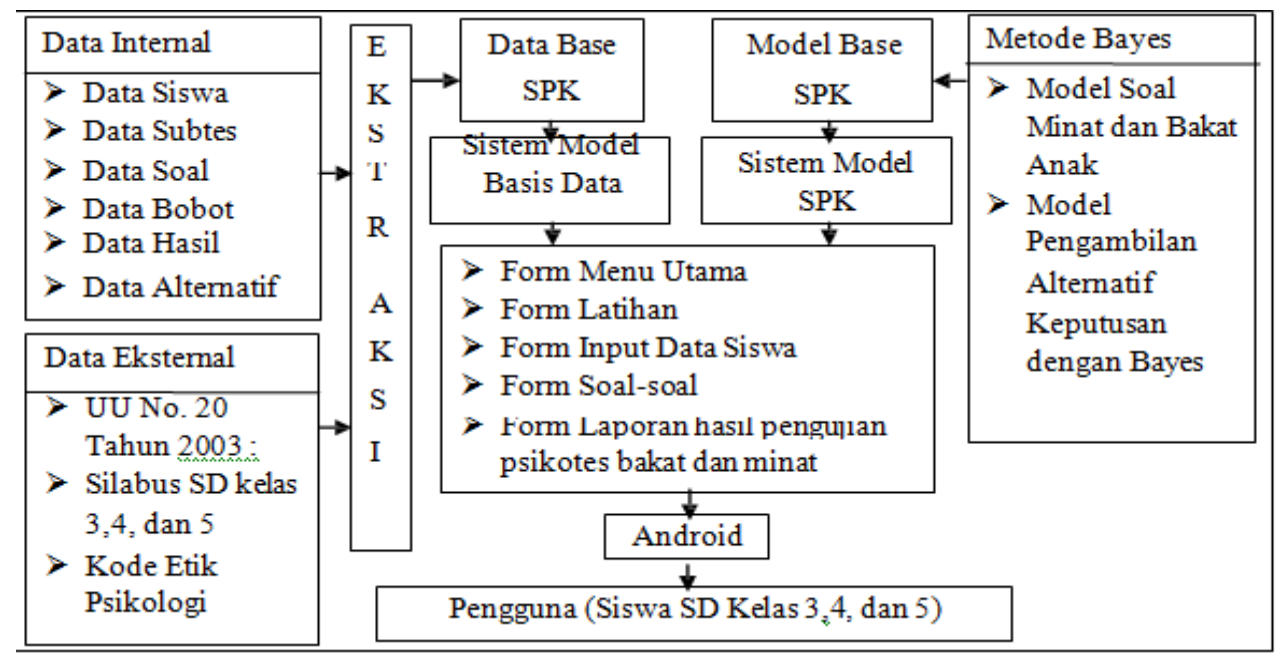

Gambar 1. Arsitektur SPK Bakat dan Minat 


\section{PERANCANGAN SISTEM}

\subsection{Pemodelan Bayesian}

Terdapat sembilan variabel kriteria yang digunakan dalam penentuan bakat dan minat anak SD kelas 3, 4 dan 5. Meliputi, Pengetahuan umum, Matematika, Ilmu Pengetahuan Alam, Ilmu Pengetahuan Sosial, Bahasa Indonesia, Bahasa Inggris, Antonim, Menyusun gambar, dan Menginat. Setiap subtes terdiri dari 15 soal pilihan ganda yang diambil dari buku psikotes minat dan bakat dengan total waktu pengerjaan 60 menit. Jumlah jawaban benar dimasukkan ke dalam skala ordinal. Pemberian nilai diberikan oleh peneliti untuk tiap-tiap skala ordinal. Nilai yang diberikan oleh peneliti antara 1 untuk skala terkecil sampai 5 untuk skala terbesar seperti pada Tabel 1.

Tabel 1. Skala Ordinal

\begin{tabular}{cccc}
\hline No. & Soal Benar & Keterangan & Nilai \\
\hline 1 & $1-4$ & Sangat Kurang & 1 \\
\hline 2 & $5-8$ & Kurang & 2 \\
\hline 3 & $9-12$ & Cukup & 3 \\
\hline 4 & $13-16$ & Baik & 4 \\
\hline 5 & $17-20$ & Sangat Baik & 5 \\
\hline
\end{tabular}

Berdasarkan Tabel 1, maka rata-rata nilai skala ordinal dapat dihitung dengan persamaan 1.

Rata-rata $=\frac{\sum \text { nilai }}{n}$

Dimana:

$\Sigma$ Nilai $=$ Total seluruh nilai hasil konfersi skala ordinal

$\mathrm{n}=$ Jumlah pembagian skala ordinal yang ada

Rata - rata $=(1+2+3+4+5) / 5$

Rata - rata $=15 / 5$

Rata - rata $=3$

Sedangkan untuk variabel alternatif, dapat dimodelkan seperti yang ada pada Tabel 2.

TabeL 2. Tabel Model Keputusan

\begin{tabular}{|c|c|c|c|c|c|c|c|c|c|}
\hline \multirow{2}{*}{ Alternatif } & \multicolumn{9}{|c|}{ Subtes/Kriteria } \\
\hline & $\mathbf{A}$ & B & $\mathbf{C}$ & D & $\mathbf{E}$ & $\mathbf{F}$ & $\mathbf{G}$ & $\mathbf{H}$ & $\mathbf{I}$ \\
\hline Verbal & 5 & 2 & 2 & 2 & 4 & 4 & 5 & 3 & 3 \\
\hline Numerik & 4 & 5 & 4 & 2 & 2 & 2 & 2 & 2 & 4 \\
\hline Spasial & 5 & 4 & 4 & 2 & 3 & 3 & 3 & 4 & 3 \\
\hline Memori & 4 & 3 & 2 & 4 & 2 & 2 & 2 & 4 & 5 \\
\hline Reasoning & 4 & 2 & 2 & 2 & 5 & 4 & 4 & 2 & 4 \\
\hline
\end{tabular}

Keterangan Tabel 2 :

A $=$ Pengetahuan Umum

$\mathrm{B}=$ Matematika

$\mathrm{C}=\mathrm{IPA}$

$\mathrm{D}=\mathrm{IPS}$

$\mathrm{E}=$ Bahasa Indonesia

$\mathrm{F}=$ Bahasa Inggris

$\mathrm{G}=$ Antonim

$\mathrm{H}=$ Gambar

$\mathrm{I}=$ Mengingat

Perhitungan bobot dari tiap kriteria menggunakan rumus seperti pada persamaan 2 .

Bobot $=$ Jumlah Nilai / Banyak Nilai

Dimana:

Jumlah Nilai $=$ Total seluruh nilai subtes di tiap alternatif

Banyak Nilai = Banyak alternatif 
Berdasarkan perhitungan pada persamaan 1 dan 2, maka diperoleh hasil perhitungan seperti yang ditunjukan pada Tabel 3 .

Tabel 3. Tabel Bobot Bayes

\begin{tabular}{llllllllll}
\hline Alternatif & P.umum & Matematika & IPA & IPS & B.Indo & B.Inggris & Antonim & Gambar & Mengingat \\
\hline Verbal & 5 & 2 & 2 & 2 & 4 & 4 & 5 & 3 & 3 \\
\hline Numerik & 4 & 5 & 4 & 2 & 2 & 2 & 2 & 2 & 4 \\
\hline Spasial & 5 & 4 & 4 & 2 & 3 & 3 & 3 & 4 & 3 \\
\hline Memori & 4 & 3 & 2 & 4 & 2 & 2 & 2 & 4 & 5 \\
\hline Reasoning & 4 & 2 & 2 & 2 & 5 & 4 & 4 & 2 & 4 \\
\hline Total & 22 & 16 & 14 & 12 & 16 & 15 & 16 & 15 & 19 \\
\hline Bobot & 4,4 & 3,2 & 2,8 & 2,4 & 3,2 & 3 & 3,2 & 3 & 3,8 \\
\hline
\end{tabular}

Total Nilai $i_{i}=\sum_{j=1}^{m}$ Nilai $_{i j} \cdot\left(\right.$ kriteria $\left._{j}\right)$

Dimana :

Total Nilai i = total nilai akhir dari alternatif ke-i;

Nilai ij = nilai dari alternatif ke-i pada kriteria ke-j;

Kriteria $\mathrm{j}=$ tingkat kepentingan (bobot) kriteria ke-j;

$\mathrm{i}=1,2,3, . . \mathrm{n} ; \mathrm{n}=$ jumlah alternatif $\mathrm{j}=1,2,3, . . \mathrm{m}$;

$\mathrm{m}=$ jumlah kriteria

Berdasarkan persamaan 3, diperoleh Pemodelan bayes seperti ditunjukan pada Tabel 4.

Tabel 4. Pemodelan Bayes

\begin{tabular}{lllllllllll}
\hline \multirow{2}{*}{ Alternatif } & \multicolumn{1}{c}{\begin{tabular}{l} 
Matematik \\
\cline { 2 - 12 }
\end{tabular}} & IPA & IPS & B.Indo & B.Inggris & Antonim & Gambar & Mengingat & N.Alternatif \\
\hline Verbal & 5 & 2 & 2 & 2 & 4 & 4 & 5 & 3 & 3 & 100 \\
\hline Numerik & 4 & 5 & 4 & 2 & 2 & 2 & 2 & 2 & 4 & 89,6 \\
\hline Spasial & 5 & 4 & 4 & 2 & 3 & 3 & 3 & 4 & 3 & 102,4 \\
\hline Memori & 4 & 3 & 2 & 4 & 2 & 2 & 2 & 4 & 5 & 92,2 \\
\hline Reasoning & 4 & 2 & 2 & 2 & 5 & 4 & 4 & 2 & 4 & 96,4 \\
\hline Total & 22 & 16 & 18 & 12 & 16 & 15 & 16 & 15 & 19 & - \\
\hline Bobot & 4,4 & 3,2 & 3,6 & 2,4 & 3,2 & 2,8 & 3 & 3 & 3,6 & - \\
\hline
\end{tabular}

\subsection{Pemodelan Sistem}

Menggunakan pemodelan UML dengan beberapa diagram yang digunakan, diantaranya use case diagram, activity diagram, sequence diagram, dan class diagram.

\subsubsection{Use Case Diagram}

Use case diagram bakat dan minat ditunjukan pada Gambar 2. Dimana, terdapat sebuah aktor 'Siswa' dengan lima use case. Terdapat tiga Use case utama yaitum use case menjawab soal, use case latihan soal dan use case melihat score. Terdapat hubungan include antara use case Input data anak dengan use case menjawab soal, yang berarti siswa harus melakukan input data sebelum menjawab soal. Sementara itu terdapat hubungan extends antara use case case menjawab soal dan use case melihat hasil alternatif, yang berarti setelah menjawab soal siswa dapat melihat hasil alternatif. Didalan use case diagram menjawab soal terdapat proses untuk menghitung bobot bayes, yang dapat dilihat proses detailnya pada sequence diagram.

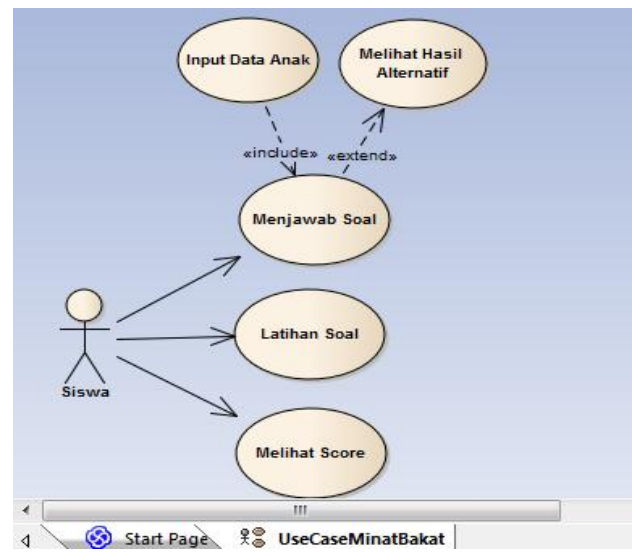

Gambar 2. Use Case Diagram Bakat dan Minat 


\subsubsection{Activity Diagram}

Activity diagram pada Gambar 3 menunjukan aliran aktifitas yang dapat dilakukan dengan aplikasi yang akan dibangun. Dimana urutannya user dapat melakukan input data, menjawab soal dan melihat hasil alternatif.

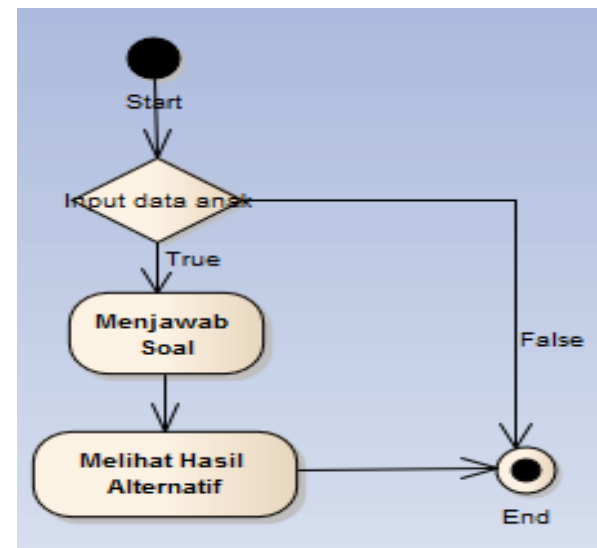

Gambar 3. Activity Diagram Menjawab Soal

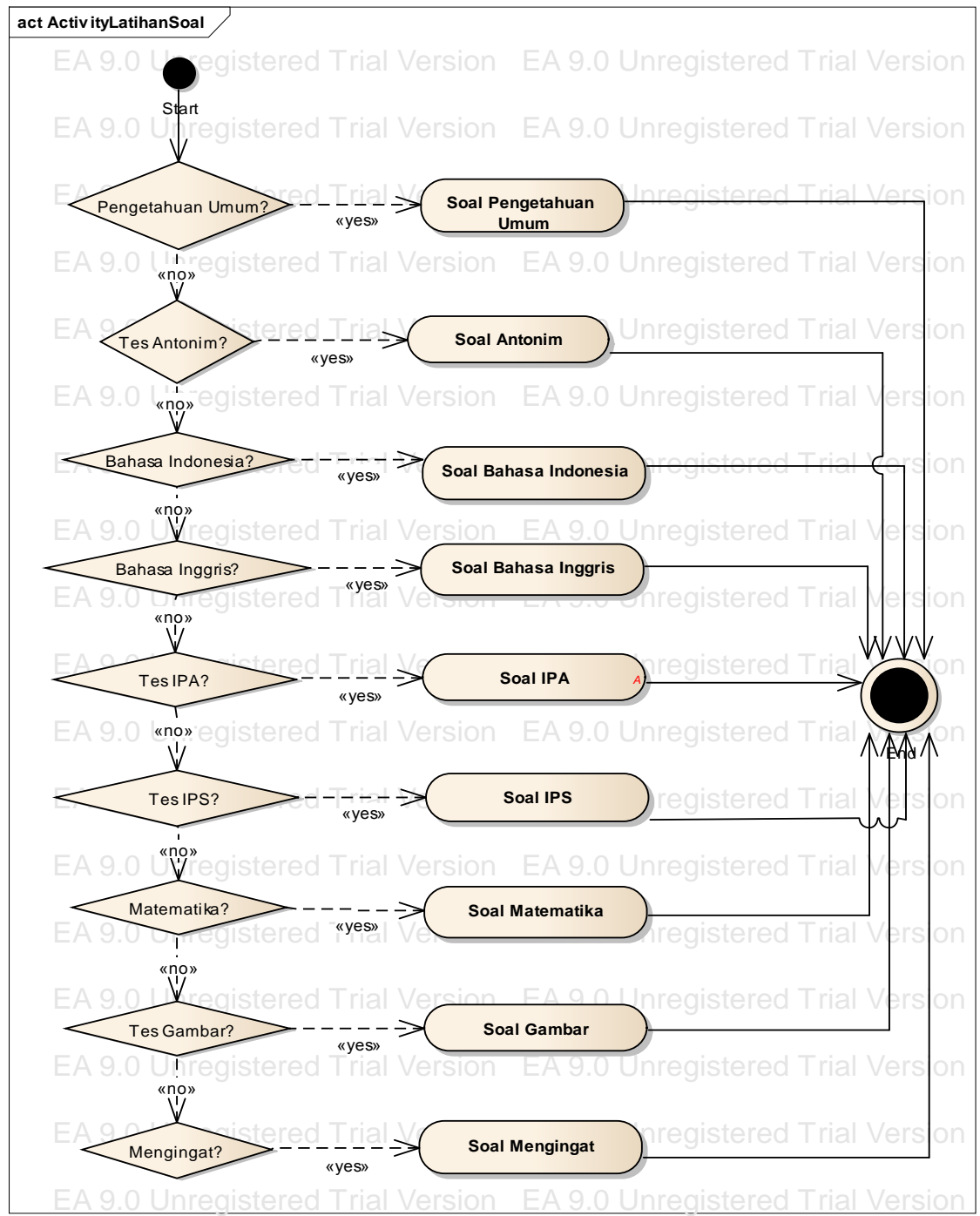

Gambar 4. Activity Diagram Latihan Soal 
Gambar 4 merupakan activity diagram latihan soal. Dimana terdapat sembilan jenis subtes soal yang akan diuji. User dapar memilih subtes mana yang akan dilatih. Sementara Gambar 5 merupakan activity diagram untuk melihat nilai. Nilai yang ditampilkan merupakan nilai - nilai dari tiap user yang telah melakukan aktifitas menjawab soal.

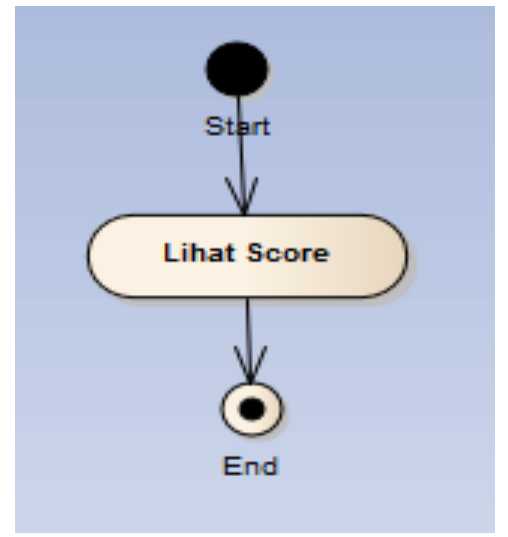

\section{Gambar 5. Activity Diagram Lihat Score}

\subsubsection{Sequence Diagram}

Sequence diagram menggambarkan urutan fisik dari sistem yang berjalan. Gambar 6 merupakan sequence diagram input data diri. Terdapat sebuah aktor, dengan tiga class. Class Interface Input Data, Class Controller Database Helper, dan class entitas Siswa.

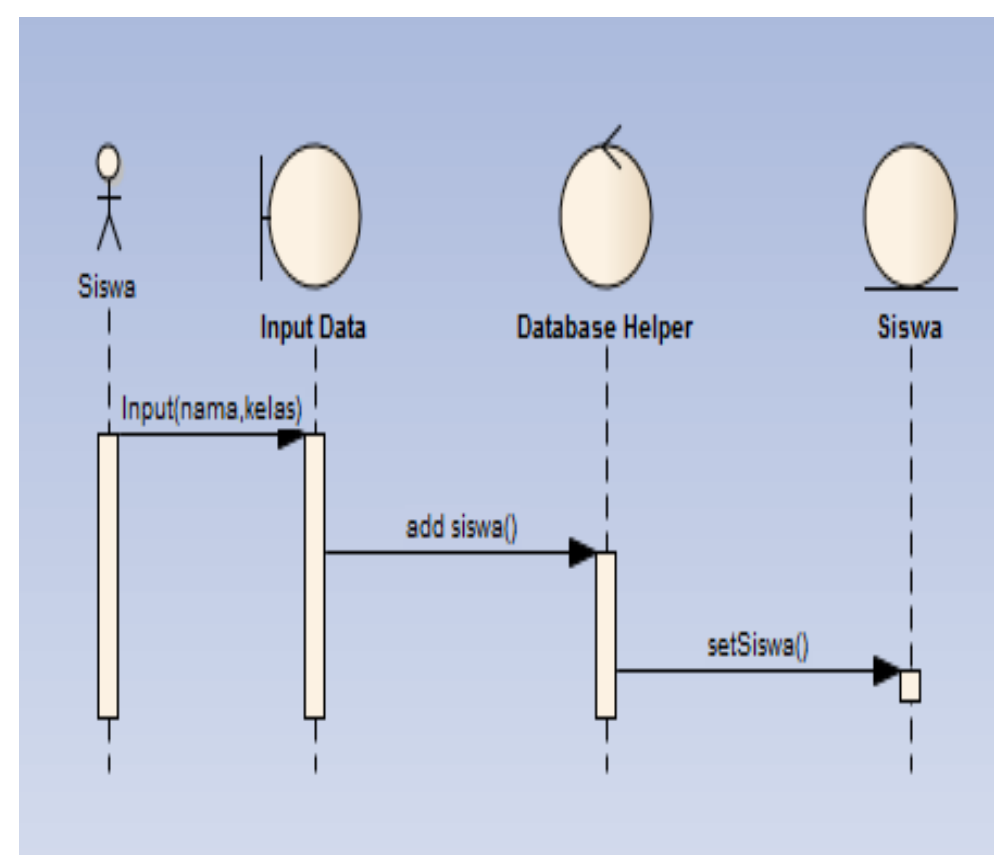

Gambar 6. Sequence Diagram Input Data Diri

Gambar 7 merupakan sequence diagram menjawab soal. Dimana terdapat empat class, yaitu Start Activity, Database Helper, Class entitas soal dan class entitas subtes. 


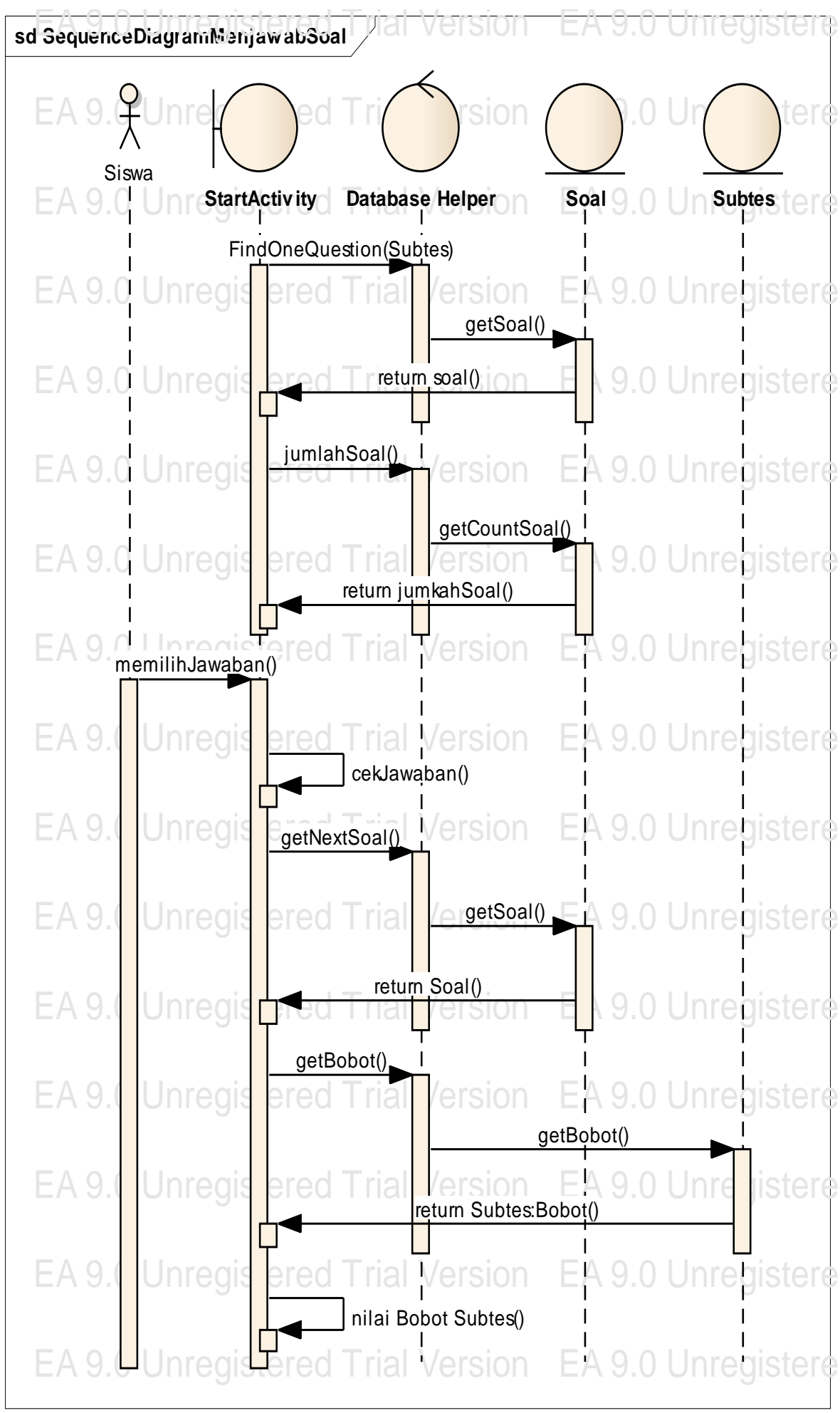

Gambar 7. Sequence Diagram Menjawab Soal

Gambar 8 dan Gambar 9 merupakan Sequence Diagram Latihan Soal dan Sequence Diagram Lihat Score dengan alur nya masing-masing. 


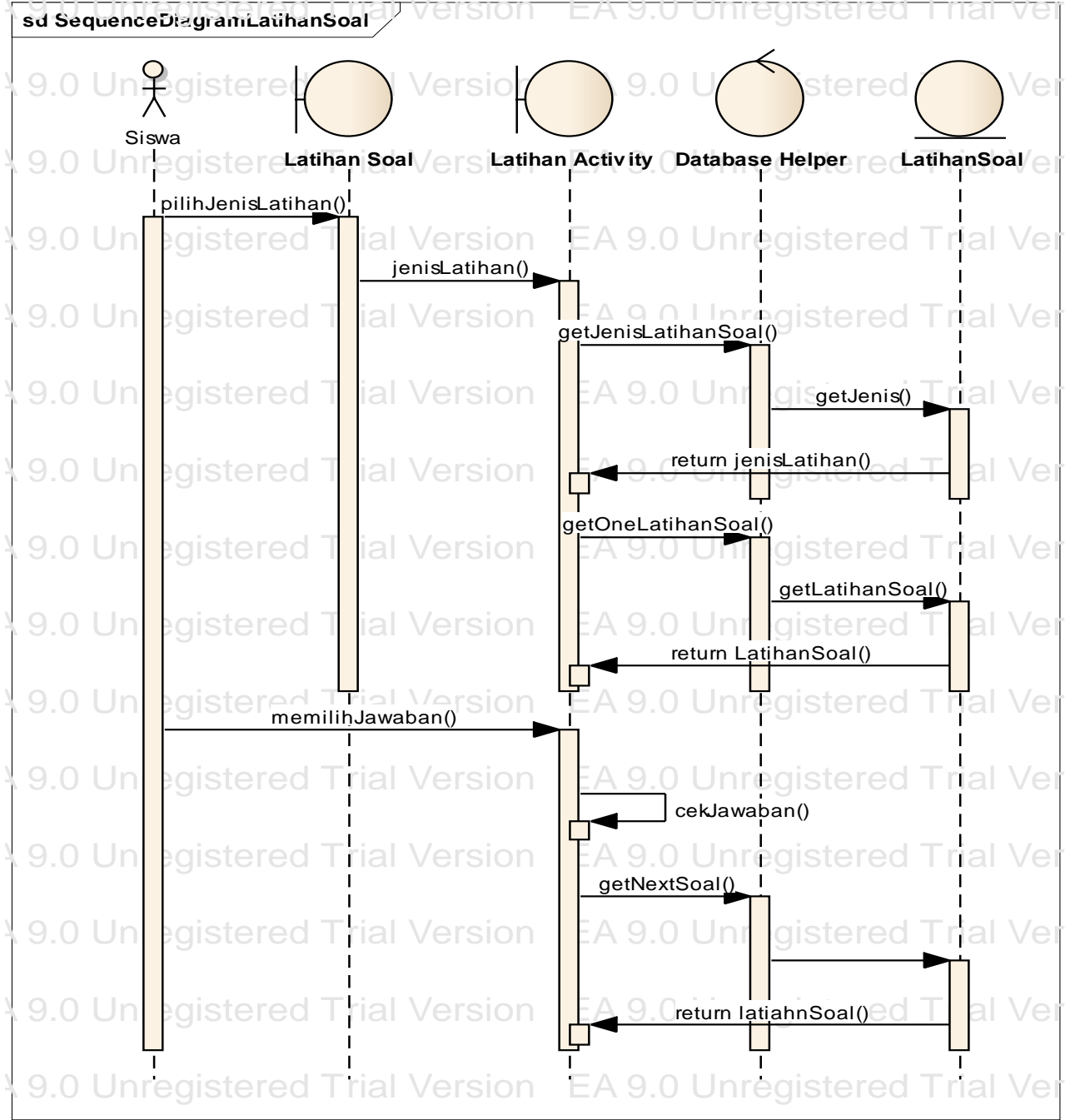

Gambar 8. Sequence Diagram Latihan Soal
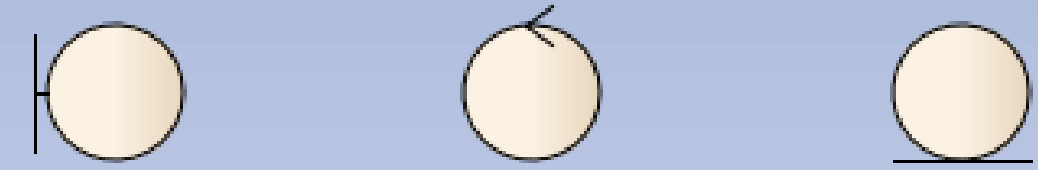

Score Activity

Database Helper

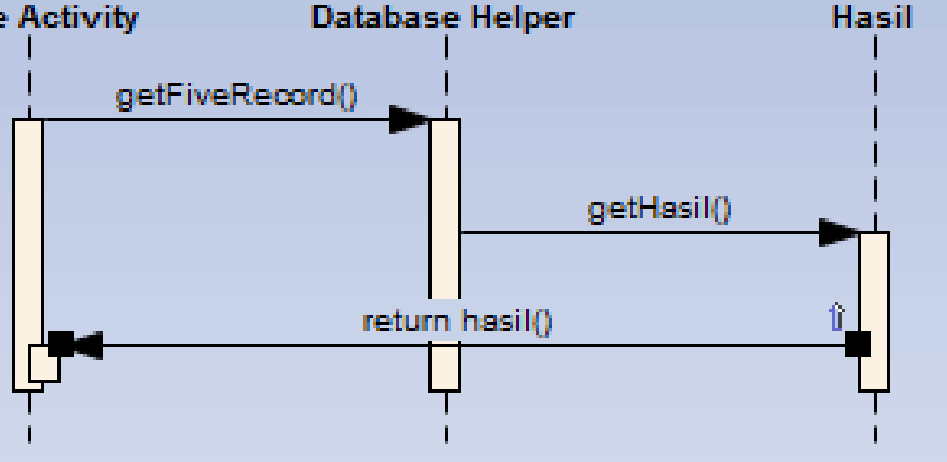

Gambar 9. Sequence Diagram Lihat Score 


\subsubsection{Class Diagram}

Class Diagram menggambarkan hubungan antar class yang dibangun. Pada Gambar.10 terdapat enam class yang saling berelasi.

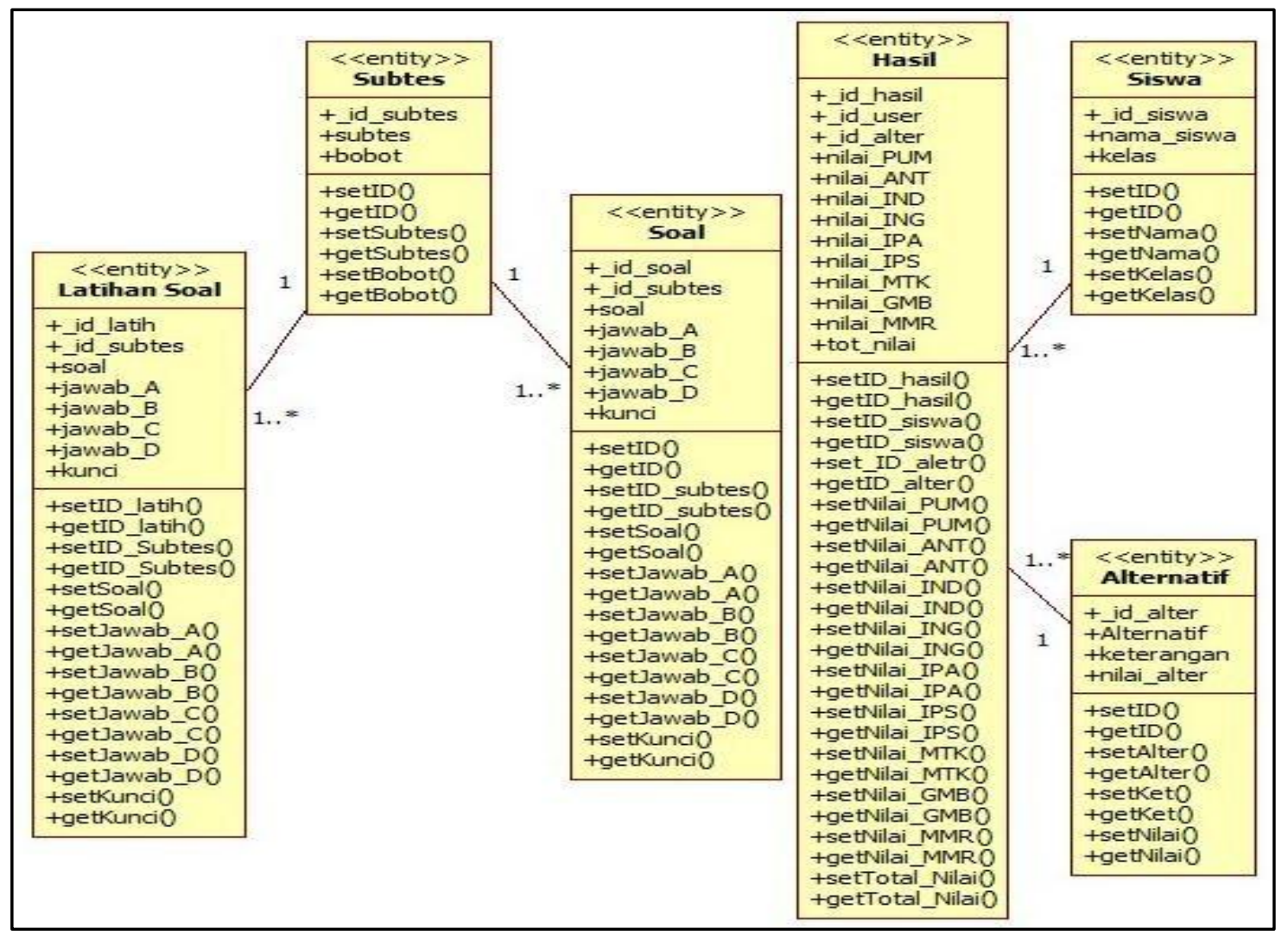

Gambar 10. Class Diagram Bakat dan Minat

\section{KESIMPULAN}

1) Telah dilakukan analisa terhadap kebutuhan sistem yang akan dibangun. Menghasilkan data internal dan eksternal yang digunakan dalam membangun sistem.

2) Pemodelan bayesian dengan lima alternatif (verbal, numerik, spasial, memori, dan reasoning) menghasilkan bobot untuk sembilan parameter antara lain, Pengetahuan umum =4,4; Matematika = 3,2; IPA=2,8; IPS=2,4; Bahasa Indonesia=3,2; Bahasa Inggris=3; Antonim=3,2; Gambar=3; dan Mengingat $=3,8$.

3) Telah dilakukan perancangan dengan menggunakan beberapa diagram UML antara lain, use case diagram, activity diagram, sequence diagram dan class diagram. Dengan adanya perancangan ini, dapat digunakan sebagai dasar dalam membangun sistem kedepan.

\section{DAFTAR PUSTAKA}

[1] Ahmadi, A. dan Sholeh M., 2005, Psikologi Perkembangan, PT. Rineka Cipta, Jakarta.

[2] Kusumo, I., 2011, Pengembangan Aplikasi Sistem Pendukung Keputusan dalam Pemilihan Fakultas di Perguruan Tinggi Berbasis Mobile Web. Teknik Informatika, UIN Syarif Hidayatullah, Jakarta.

[3] Pramono, H., 2012, Perancangan Situs Web Psikotes Penerimaan Calon Pegawai Negeri Sipil sebagai Media Pelatihan. Teknik Informatika, Amikom, Yogyakarta.

[4] Turban, E., and Aronson, J.E., 2001, Decission Support System and Intelligent Systems, New Jersey:PrenticeHall. 
Jurnal SIMETRIS, Vol 6 No 1 April 2015

ISSN: 2252-4983

[5] Anastasya, L., dan Anggraini,L.H., 2013, Perbandingan Metode Bayes dan Analisi GAP dalam Implementasi Sistem Pendukung Keputusan untuk Pemilihan SIM Card, Jurnal Simetris, Vol.3 No.1, UMK. 